\section{Transmission of Phenotypic Variability within a Pure Line}

In the course of a study of the genetic and environmental factors controlling heat resistance in peas (Pisum sativum), it was found that when the source of pollen was non-uniform with respect to the environment under which it was developed, the $F_{1}$ population exhibited a variance in growth which exceeded considerably that of either parent. Upon analysis of the results it was found that the excessive variance could be attributed entirely to the difference among the environments of the different pollen sources. This suggested that there may be a carry-over by the pollen of environmental influences on the pollen parent.

Two inbred lines of peas were used in these experiments, both lines having been inbred since the early 1930 's. It is therefore most likely that these two lines, which have gone through an intensive inbreeding and selection programme extending for some $20-$ 25 years, are for all practical purposes homozygous. All the experiments were performed in the Earhart Plant Research Laboratory. A description of this Laboratory and the experimental facilities available in it has been given by Went'.

The seeds of both varieties were planted in either constant temperature - artificial light chambers, or in controlled fluctuating temperatures in greenhouses with natural light supplemented by artificial light to make a 16-hr. photoperiod. The temperature fluctuation of the greenhouse consists of a constant temperature during the day period and a constant but lower temperature during the night period.

Crosses were made between the two varieties used in these experiments and within each variety. The crosses were made in the following manner. The plants used as females were grown in a greenhouse with 16-hr. photoperiod and a controlled day tem. perature of $20^{\circ} \mathrm{C}$. and a night temperature of $14^{\circ} \mathrm{C}$. These plants were pollinated with pollen from plants growing in different constant temperatures. The $F_{1}$ progenies from these crosses were grown at $26^{\circ} \mathrm{C}$., 16-hr. photoperiod, to test for heat resistance. It was during this phase of the experiments that differences in the growth characteristics among members of the $F_{1}$ population were observed. These differences are related to the temperatures in which the pollen donors had grown.

Table 1 summarizes the results of one experiment and shows the manner in which the crosses were made. A significant difference among pollen sources is shown by the significant differences in the growth behaviour of the three different groups.

Table 2 is a summary of the analysis variance of four separate experiments. In each experiment the contribution to the total variance caused by differences in pollen source, is significant.

Table 1. The EFfect of Growth Temperatore of The PollenDONOR ON THE GROWTH CHARACTERISTICS OF THE $F$, PROQENY GROWN AT $26^{\circ} \mathrm{C}$. ALL PLANTS GROWN ON A 16-HR. PHOTOPERIOD. FEMALE PARENTS GROWN AT $20^{\circ} \mathrm{C}$. DURING LIG

\begin{tabular}{|c|c|c|c|c|}
\hline & \multicolumn{3}{|c|}{ Growth of $F_{1}$ progeny } \\
\hline $\begin{array}{l}\text { Pollen-donor } \\
\text { Deg. C. dur- } \\
\text { ing light } \\
\text { period }\end{array}$ & $\begin{array}{l}\text { s grown at : } \\
\text { Deg. C. dur- } \\
\text { ing dark } \\
\text { period }\end{array}$ & $\begin{array}{l}\text { No. of } \\
\text { nodes } \\
\text { formed }\end{array}$ & $\begin{array}{c}\text { Growth-rate } \\
\text { (cm./day) }\end{array}$ & $\begin{array}{l}\text { Final } \\
\text { height } \\
\text { (cm.) }\end{array}$ \\
\hline $\begin{array}{l}20 \\
14 \\
26\end{array}$ & $\begin{array}{l}14 \\
14 \\
26\end{array}$ & $\begin{array}{l}14 \\
11 \cdot 6 \\
12\end{array}$ & $\begin{array}{l}0.544 \pm 0.018 \\
0 \cdot 609 \pm 0.016 \\
0 \cdot 679 \pm 0.032\end{array}$ & $\begin{array}{l}7 \cdot 68 \pm 0 \cdot 18 \\
8 \cdot 45 \pm 0 \cdot 10 \\
9 \cdot 38 \pm 0 \cdot 24\end{array}$ \\
\hline
\end{tabular}

Table 2. ANaLysis of Variance

Summaries showing effects of differences in growth temperature among pollen parents on the growth-rates of their progeny

\begin{tabular}{|c|c|c|c|c|c|c|c|c|}
\hline Source & \multicolumn{2}{|c|}{$\begin{array}{l}\text { Exp. I } \\
\text { Unica } \times \\
\text { Unica } \\
\text { d.f. M.S. }\end{array}$} & \multicolumn{2}{|c|}{$\begin{array}{l}\text { Exp. II } \\
\text { Unica } \times \\
L_{5} \\
\text { d.f. II.S. }\end{array}$} & \multicolumn{2}{|c|}{$\begin{array}{l}\text { Exp. III } \\
L_{\mathrm{s}} \times L_{\mathrm{s}} \\
\text { d.f. MI.S. }\end{array}$} & \multicolumn{2}{|c|}{$\begin{array}{c}\text { Exp. IV } \\
L_{5} \times \\
\text { Vnica } \\
\text { d.f. M.S. }\end{array}$} \\
\hline $\begin{array}{l}\text { Between } \\
\text { pollen } \\
\text { sources } \\
\text { Within pollen }\end{array}$ & 3 & $2 \cdot 67^{*}$ & 2 & $3 \cdot 19^{*}$ & 4 & $1 \cdot 51 \dagger$ & 1 & $6 \cdot 48^{*}$ \\
\hline sourees & 20 & $0 \cdot 32$ & 9 & $0 \cdot 16$ & 20 & $0 \cdot 49$ & 7 & $0 \cdot 27$ \\
\hline
\end{tabular}

* Significant at 1 per cent level. † Significant at 5 per cent level.

These experiments, along with others ${ }^{2}$ which have shown that differences can be produced in the growth characteristics of pea plants as a result of the effect of the environment on previous generations, are remarkably similar to those reported by Durrant $^{3}$ in flax.

Further studies of the relationship between the previous environment and the effect on the progeny are in progress and will be reported in due course. This work was supported by a grant from the National Science Foundation, Grant No. G1385.

\section{H. R. HighKIN}

Division of Biology,

California Institute of Technology, Pasadena.

Sept. 3.

"Went, F. W., "Experimental Control of Plant Growth" (Chronica Botanica 'Co., Waltharn, Mass., 1957).

${ }^{2}$ Amer. J. Bot. (in the press).

surrant, A., Nature, 181, 928 (1958).

\section{Silicification of Branched Cells in the Leaves of Nardus stricta L.}

Attention has been directed ${ }^{1}$ to the presence of certain peculiar branched rods of opaline silica in the leaves of Nardus stricta and in the soils on which this species grows. Although transverse sections of leaves of $N$. stricta figured by $\mathrm{Grob}^{2}$ and $\mathrm{Hegi}^{3}$ show what are apparently the minute hat-like opals which we have detected even in the very young leaves, we have found no reference depicting or describing the branched rods which we detect in surface preparations of older leaves after rendering them transparent, for example, by controlled treatment with chromic acid (Fig. 1). The branched cells which secrete these bodies, although not present in the seedling leaves, develop later on the well-marked ribs of the upper surface (Figs. 2 and 3 ), and their protruding portions can be identified with what have been deseribed as asperities ${ }^{4}$ or papill ${ }^{2}$. The protrusions tend to be longest near the crest of the rib, diminishing laterally to give every gradation from well-branched to unbranched long cells (Figs. 4 and 5).

This structure, with its end-to-end arrangement of long cells, is quite distinct from those involving the common types of trichome, and although we have examined many species of grasses we have seen it only in $N$. stricta. Stebbins ${ }^{5}$ suggests that a distinctive genus such as Nardus, with its single species, may represent the last remains of some evolutionary line now almost extinct, or the culmination of a trend which has been successful in one specialized. sphere. If it should be confirmed that no other grass besides $N$. stricta exhibits these branched cells and branched opaline bodies, it would give additional support to such theories. 